九州大学学術情報リポジトリ

Kyushu University Institutional Repository

Reassessment of Pigmentation Patterns used for Ident ifying Leptocephali (Gnathophis heterognathos and G. ginanago) Collected from the Kuroshio-0yashio transition region

Takahashi, Masanori

National Research Institute of Fisheries and Environment of Inland Sea, Fisheries Research Agency

Kobayakawa, Midori

Department of Biology, Graduate school of Sciences, Kyushu University

Mochioka, Noritaka

Laboratory of Fisheries biology, Division of Marine Bioresources, Faculty of Agriculture, Kyushu University

https://doi.org/10.5109/1564089

出版情報: 九州大学大学院農学研究院紀要. 61 (1)，pp.103-108，2016-02-29. Faculty of Agriculture, Kyushu University

バージョン :

権利関係 : 


\title{
Reassessment of Pigmentation Patterns used for Identifying Leptocephali (Gnathophis heterognathos and G. ginanago) Collected from the Kuroshio-Oyashio transition region
}

\author{
Masanori TAKAHASHI ${ }^{1}$, Midori KOBAYAKAWA ${ }^{2}$ \\ and Noritaka MOCHIOKA*
}

\author{
Laboratory of Fisheries biology, Division of Marine Bioresources, Faculty of Agriculture, \\ Kyushu University, 6-10-1 Hakozaki, Fukuoka, 812-8581, Japan \\ (Received November 4, 2015 and accepted November 19, 2015)
}

\begin{abstract}
Identification of leptocephali of Gnathophis heterognathos and G. ginanago, the most abundant leptocephali in Japanese water, is usually identified based on morphological characteristics such as total number of myomeres (TM), number of myomeres of anterior to the last vertical blood vessel (VBV last) and presence or absence of melanophores on the lateral surface of the posterior spinal cord. However, because some of individuals collected in the Kuroshio-Oyashio transition region differed from the norm in the above characters, the validity of the last-mentioned was examined using the mitochondrial DNA 16S rRNA gene to provide genetic evidence. A total of 394 leptocephali were classified into following four morphotypes, Types A1 (TM: 117-128, VBV last: 36-44, pigmentation: absent, Body height (BH)/Total length (TL) ratio: 0.083-0.123), A2(TM: 119-126, VBV last: 40-44, pigmentation: present, BH/TL ratio: 0.082-0.127), B1(TM: 125-134, VBV last: 41-48, pigmentation: present, BH/TL ratio: 0.093-0.137) and B2(TM: 125-135, VBV last: 43-48, pigmentation: absent, BH/TL ratio: 0.080-0.139). Group A showed lower TM, VBV last, and BH/TL ratio than those of Group B. Molecular evidence confirmed that, Groups A (Types A1 and A2) and B (Types B1 and B2) were in fact $G$. heterognathos and $G$. ginanago, respectively. In addition, relationship of total length and pre-anal myomere (PAM)/TM ratio as an indicator of metamorphosis showed that the presence of posterior spinal cord melanophores was depended on their growth. These results indicate that Gnathophis leptocephali obtained from the Kuroshio-Oyashio transition region were comprising only the two species, and that variations in the pigmentation pattern characters rendered them unsuitable for identification purposes. Combination of above morphometric or meristic characters is effective for identified these two species.
\end{abstract}

Key words: $16 \mathrm{~S}$ rRNA, Gnathophis leptocephali, posterior spinal cord melanophores

\section{INTRODUCTION}

Elopiformes, Albuliformes, Notacanthiformes and Anguilliformes have been included in Elopomorpha on the basis of their leaf-like larval form, termed "leptocephalus" (Greenwood et al., 1966). Of those orders, Anguilliformes is the largest group including about 791 species in 141 genera, representing 15 families (Nelson, 2006). As yet, a great many questions (e.g. natural habitat of leptocephali) to be solved (Smith, 1989), the lifecycle of most species being poorly known as a consequence. Although information on leptocephali collected in offshore regions is highly important in the elucidation of the lifecycles of anguilliform fishes, classification of such leptocephali is often being difficult, many species not yet being attributable to specific families (Smith, 1989).

On the other hand, of the 17 families, 69 genera and 163 species of adult Anguilliform fishes known from Japan (Hatooka, 2013), only 33 species of leptocephali have been reported from the Japan region (Mochioka et al., 2014; Tawa and Mochioka, 2009; Tawa et al., 2012). To clarify the lifecycle of such as anguilliform and other elo-

\footnotetext{
National Research Institute of Fisheries and Environment of Inland Sea, Fisheries Research Agency, 2-17-5 Maruishi, Hatsukaichi, Hiroshima 739-0452, Japan

2 Department of Biology, Graduate school of Sciences, Kyushu University, 6-10-1 Hakozaki, Fukuoka, 812-8581, Japan

* Corresponding author (E-mail: mochioka@agr.kyushu-u.ac.jp)
}

pomorph fishes, it is necessary to identify leptocephali at the species level.

The most abundant leptocephali around Japan were Gnathophis spp., including $G$. heterognathos and $G$. ginanago (Mochioka et al., 2014; Uematsu et al., 1990; Uematsu et al., 1992; Miya and Hirosawa, 1994; Mochioka et al., 2001; Miller et al., 2002; Takahashi et al., 2008). Although $G$. heterognathos and $G$. ginanago have been separated on the basis of total number of myomeres (TM: 116-128 vs 123-139, respectively), number of myomeres anterior to the last vertical blood vessel (VBV last: 36-45 vs 41-50), body height, and absence (presence) of melanophores on the lateral surface of the posterior spinal cord (Tabeta and Mochioka, 1988), description about melanophores for to separate these two species have been removed in recent study (Mochioka et al., 2014). It caused by some specimens collected from the KuroshioOyashio transition region (transition region) that were equivocal in their affinities. But the details of such morphological features have not been mentioned.

The only consistent morphological characteristics that are transferred through metamorphosis of Elopomorpha species is the number of myomeres (in larvae), which match the number of vertebrae (in adults) (Smith, 1979). However, many species have overlapping myomere/vertebral numbers. Accordingly, matching of larvae and adults is best done by collecting series samples of each growth stage (Mochioka et al., 2014; Tawa 
and Mochioka, 2009), although sample collection especially in offshore waters is sometimes difficult and at best offers only fragmentary information, making identifications difficult. In the present study, myomere numbers and pigmentation pattern were used to classify leptocephali, supported by species-specific DNA sequence. Molecular identification has frequently been applied in recent years to eggs and leptocephali of a number of anguilliform species (e.g. Aoyama et al., 2001; Watanabe et al., 2004; Ma et al., 2005, 2007; Kimura et al., 2006; Kurogi, 2008), successfully demonstrating the validity of using the mitochondrial DNA 16S rRNA gene for such species. This study focused on Gnathophis leptocephali, reexamined the current morphological classification of the genus using for comparison mitochondrial DNA 16S rRNA gene sequence analysis.

\section{MATERIALS AND METHODS}

\section{Specimens}

A total of 394 Gnathophis leptocephali were collected at night from the transition region $\left(140^{\circ}-160^{\circ} \mathrm{E}\right.$, $35^{\circ}-40^{\circ} \mathrm{N}$ ) (Fig. 1) with a mid water trawl net (Model JP-1, Nichimo Co., Ltd.) towed in the surface layer $(<$ $30 \mathrm{~m}$ depth) at a speed of ca. 3.5 knots for 30 minutes by the T/V Hokuho Maru (664 gross tonnage, $2200 \mathrm{hp}$ ), chartered by the National Research Institute of Fisheries Science during 8-30 May 2002. The trawl net had a total length of $89 \mathrm{~m}$, opening area of about $530 \mathrm{~m}^{2}$, mesh sizes of $57-1000 \mathrm{~mm}$, and $8 \mathrm{~mm}$ meshed cod end. Leptocephali specimens were initially stored in sea water at $-30^{\circ} \mathrm{C}$, and after thawing and measurement, preserved in $99.5 \%$ ethanol. Morphometric and meristic characters (total length: TL, pre-dorsal length: PDL, pre-anal langth: PAL, head length: HL, eye diameter: ED, maximum body height: $\mathrm{BH}$, total myomere: TM, pre-dorsal myomere: PDM, pre-anal myomere: PAM, number of myomere on first vertical blood vessel: VBV 1st, number of myomere on last vertical blood vessel: VBV last) were measured or counted. Measurement and myomere counting methods followed Mochioka et al. (2014). PAM/TM ratio was calculated for to estimate their metamorphic stage (e.g.

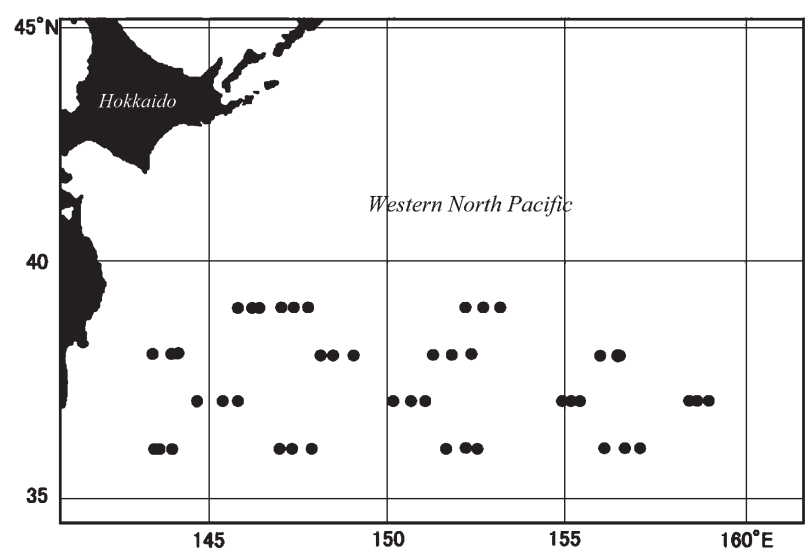

Fig. 1. Sampling locations of leptocephali in the Kuroshio-Oyashio transition region during a cruise of the T/V Hokuho Maru (8-30 May 2002).
Tanaka et al., 1987; Lee and Byun, 1996). These specimens were classified into four morphotypes, Types A1, A2, B1 and B2 based on TM, VBV last, BH/TL ratio and absence (presence) of posterior spinal cord melanophores (Fig. 2). When TM or VBV last were overlapped between each type, BH/TL ratio was used for determine (details were shown in result). Types A1 $(n=5), A 2(n=4), B 1$ $(\mathrm{n}=5)$, and B2 $(\mathrm{n}=6)$ were subjected to molecular analysis. Adult specimens of $G$. heterognathos ( $\mathrm{GH}$ ad: $\mathrm{n}=6$ ) and $G$. ginanago (GG ad: n=5) were collected by trawler from Tosa bay (Kochi Pref.), off Choshi (Chiba Pref.), and off Soma (Fukushima Pref.). These samples were stored at $-20^{\circ} \mathrm{C}$. After thawing and measurement, muscle tissue samples were excised and preserved in $99.5 \%$ ethanol for DNA analysis. Measurement and counting methods followed Hatooka (2013). All specimens used in this study were deposited in the collection of the Kyushu University Museum (KYUM).

a

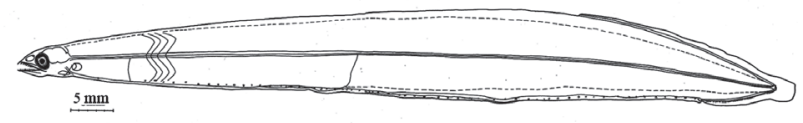

$\underline{\mathrm{mm}}$

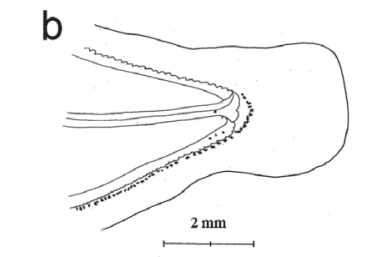

C

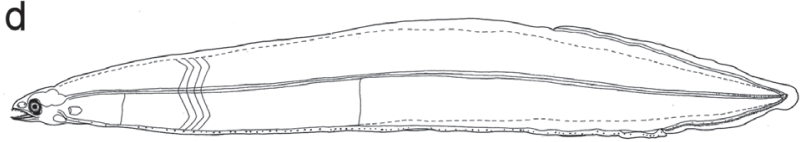

$5 \mathrm{~mm}$ e

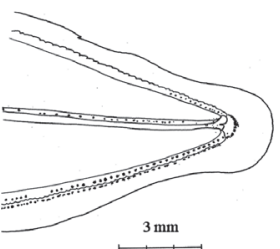

f

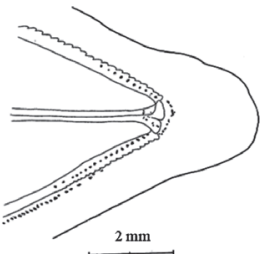

Fig. 2. Leptocephalus larvae of Gnathophis spp. (Types A1, A2, B1 and B2) collected from the Kuroshio-Oyashio transition region. a: Lateral view of Type A1. b: Tip of caudal region of Type A1. c: tip of caudal region of Type A2. d: Lateral view of Type B1. e: Tip of caudal region of Type B1. f: Tip of caudal region of Type B2.

\section{DNA extraction, amplification, and sequencing}

Muscle tissue samples were subjected to DNA extraction. Tissues were digested with Proteinase $\mathrm{K}$ at $50^{\circ} \mathrm{C}$ and DNA was purified by standard phenol: chloroform extraction and ethanol precipitation, or by using DNA extraction kits (DNeasy Tissue Kit; QIAGEN GmbH, Hilden, Germany). PCR (polymerase chain reaction) was used to amplify the partial mitochondrial DNA $16 \mathrm{~S}$ rRNA gene, in a total of $50 \mu \mathrm{l}$ volumes containing $5 \mu \mathrm{l} 10 \times$ PCR buffer, $0.2 \mathrm{mM}$ each deoxynucleosyde tri- 
phosphate (dNTP), $0.2 \mu \mathrm{M}$ each primer, 2.5 units Taq DNA polymerase (TaKaRa Ex Taq; TaKaRa, Shiga Japan) and $10 \mathrm{ng}$ template DNA. Primers RRNA-A (5'-GGTCCWRCCTGCCCAGTGA) and RRNA-B (5'-CCGGTCTGRACYAGATCACGT) for the mitochondrial DNA 16S rRNA gene were used. The thermal profile was $94^{\circ} \mathrm{C} / 40 \mathrm{~s}$ (denaturing), $50^{\circ} \mathrm{C} / 40 \mathrm{~s}$ (annealing), and $72^{\circ} \mathrm{C} / 40 \mathrm{~s}$ (extension), for 30 cycles on a TaKaRa PCR Thermal Cycler PERSONAL (TaKaRa, Shiga Japan) or PTC-100 Programmable Thermal Controller (MJ RESEARCH, Watertown, Massachusetts, USA). Amplified DNA was purified using the QIAquick PCR Purification Kit (QIAGEN, GmbH, Hilden, Germany) and sequenced directly using the BigDye Terminator Cycle Sequencing Ready Reaction Kit Ver. 2 or 3 (Applied Biosystems, Foster City, CA, USA). They were sequenced on an automated DNA sequencer (ABI Prism 3100 Genetic Analyzer). The nucleotide sequences were deposited with GenBank, the DNA database (accession numbers being AB752344-AB752374).

\section{Sequence analyses}

DNA sequences were aligned using the computer programs Edit View ver. 1.0.1 (Applied Biosystems), Genetic Mac 8.0(Software Development Co.), and ClustalX (Thompson et al., 1997). A neighbor-joining (NJ) dendrogram (Saitou and Nei, 1987) based on Kimura's two parameter model (Kimura, 1980) was constructed so as to determine the genetic relationships using the MEGA 3.1 program package (Kumar et al., 2004). Bootstrap probabilities of nodes (P) (Efron, 1979) were calculated from 1000 replications using the MEGA 3.1 program package (Kumar et al., 2004). The haplotype network, estimated with the $95 \%$ statistical limits of parsimony using the algorithm in Statistical Parsimony method (Templeton et al., 1992) was constructed by the TCS 1.21 program package (Clement et al., 2000).

\section{Materials examined}

GH ad1: KYUM-PI 1837; AB752344, GH ad2: KYUM-PI 1818; AB752345, GH ad3: KYUM-PI 1827; AB752346, GH ad4: KYUM-PI 1840; AB752347, GH ad5: KYUM-PI 1842; AB752348, GH ad6: KYUM-PI 1836; AB752349, GG ad1: KYUM-PI 1900; AB752350, GG ad2: KYUM-PI 1903; AB752351, GG ad3: KYUM-PI 1906; AB752352, GG ad4: KYUM-PI 1913; AB752353, GG ad5: KYUM-PI 1908; AB752354, Type A1-1: KYUM-PI 1780 1; AB752355, Type A1-2: KYUM-PI 1780-6; AB752356, Type A1-3: KYUM-PI 1670-16; AB752357, Type A1-4: KYUM-PI 1718-18; AB752358, Type A1-5: KYUM-PI 1799-17; AB752359, Type A2-1: KYUM-PI 1695-4; AB752360, Type A2-2: KYUM-PI 1695-5; AB752361, Type A2-3: KYUM-PI 1745-8; AB752362, Type A2-4: KYUM-PI 1753-6; AB752363, Type B1-1: KYUM-PI 1696-2; AB752364, Type B1-2: KYUM-PI 1696-8; AB752365, Type B1-3: KYUM-PI 1696-10; AB752366, Type B1-4: KYUM-PI 1746-1; AB752367, Type B1-5: KYUM-PI 1746-11; AB752368, Type B2-1: KYUM-PI 1773; AB752369, Type B2-2: KYUM-PI 1781; AB752370, Type B2-3: KYUM-PI 1713-1; AB752371, Type B2-4: KYUM-PI 1713-2; AB752372, Type B2-5: KYUM-PI 1713-4; AB752373, Type B2-6: KYUM-PI 1746-17; AB752374 (Sample ID of this study: Museum reg. no.; Accession no.).

\section{RESULTS}

\section{Morphotypes of leptocephali}

Gnathophis leptocephali collected from the Kuroshio-Oyashio transition region were first classified into two groups (Groups A and B) on the basis of TM, VBV last and BH/TL ratio (Table), with further subdivision on the basis of absence (Types A1 and B2) or presence (Types A2 and B1) of posterior spinal cord melanophores (Fig. 2, Table). Types A1 and A2 had similar TM (117-128 and 119-126, respectively), VBV last (36-44 and $40-44$, respectively) and BH/TL ratio (0.083-0.123

Table 1. Morphometric and meristic characters of each types of Gnathophis leptocephali

\begin{tabular}{|c|c|c|c|c|c|c|c|c|}
\hline $\begin{array}{l}\text { Leptocephalus } \\
\text { type }\end{array}$ & $\mathrm{n}$ & $\mathrm{TL}$ & \multicolumn{2}{|c|}{$\mathrm{BH} / \mathrm{TL}$ ratio } & \multicolumn{2}{|c|}{ Pigmentation } & & \\
\hline Type A1 & 58 & $69.6-98.9(88.3 \pm 6.1)$ & \multicolumn{2}{|c|}{$0.083-0.123(0.106 \pm 0.007)$} & \multicolumn{2}{|c|}{ Absent } & & \\
\hline Type A2 & 50 & $84.0-100.5(94.1 \pm 3.6)$ & \multicolumn{2}{|c|}{$0.082-0.127(0.109 \pm 0.008)$} & \multicolumn{2}{|c|}{ Present } & & \\
\hline Type B1 & 131 & $98.5-126.9(110.7 \pm 5.0)$ & \multicolumn{2}{|c|}{$0.093-0.137(0.120 \pm 0.008)$} & \multicolumn{2}{|c|}{ Present } & & \\
\hline Type B2 & 155 & $74.0-120.3(106.2 \pm 8.8)$ & $0.080-0.139(0$ & $18 \pm 0.009)$ & \multicolumn{2}{|c|}{ Absent } & & \\
\hline $\begin{array}{l}\text { Leptocephalus } \\
\text { type }\end{array}$ & $\mathrm{n}$ & VBV 1st & VBV last & PAM & & PDM & $\mathrm{TM}$ & $\mathrm{PAM} / \mathrm{TM}$ ratio \\
\hline Type A1 & 58 & $9-12(10.8 \pm 0.8)$ & $36-44(41.5 \pm 1.3)$ & $91-106(98.7$ & $\pm 2.9)$ & $70-97(75.7 \pm 4.8)$ & $117-128(121.8 \pm 2.5)$ & $0.74-0.85(0.81 \pm 0.02)$ \\
\hline Type A2 & 50 & $10-12(10.7 \pm 0.7)$ & $40-44(41.6 \pm 1.0)$ & $62-102(94.9$ & $\pm 6.8)$ & $45-88(72.7 \pm 5.4)$ & $119-126(122.0 \pm 2.2)$ & $0.51-0.85(0.78 \pm 0.06)$ \\
\hline Type B1 & 131 & $10-13(11.8 \pm 0.6)$ & $41-48(45.8 \pm 1.2)$ & $64-111(98.3$ & $\pm 7.9)$ & $43-90(77.8 \pm 7.7)$ & $126-134(130.0 \pm 1.8)$ & $0.50-0.83(0.76 \pm 0.06)$ \\
\hline Type B2 & 155 & $10-13(11.7 \pm 0.7)$ & $43-48(46.0 \pm 1.1)$ & $66-118(103.8$ & $\pm 4.4)$ & $39-103(83.2 \pm 5.3)$ & $125-135(129.9 \pm 2.0)$ & $0.51-0.90(0.80 \pm 0.03)$ \\
\hline
\end{tabular}

Parentheses show average \pm standard deviation. TL: total length (mm), BH: body height (mm), Pigmentation: melanophores on the lateral surface of the posterior spinal cord, VBV 1 st: 1 st vertical blood vessel myomere, VBV last.: last vertical blood vessel myomere, PAM: preanal myomere, PDM: predorsal myomere, TM: total myomere 


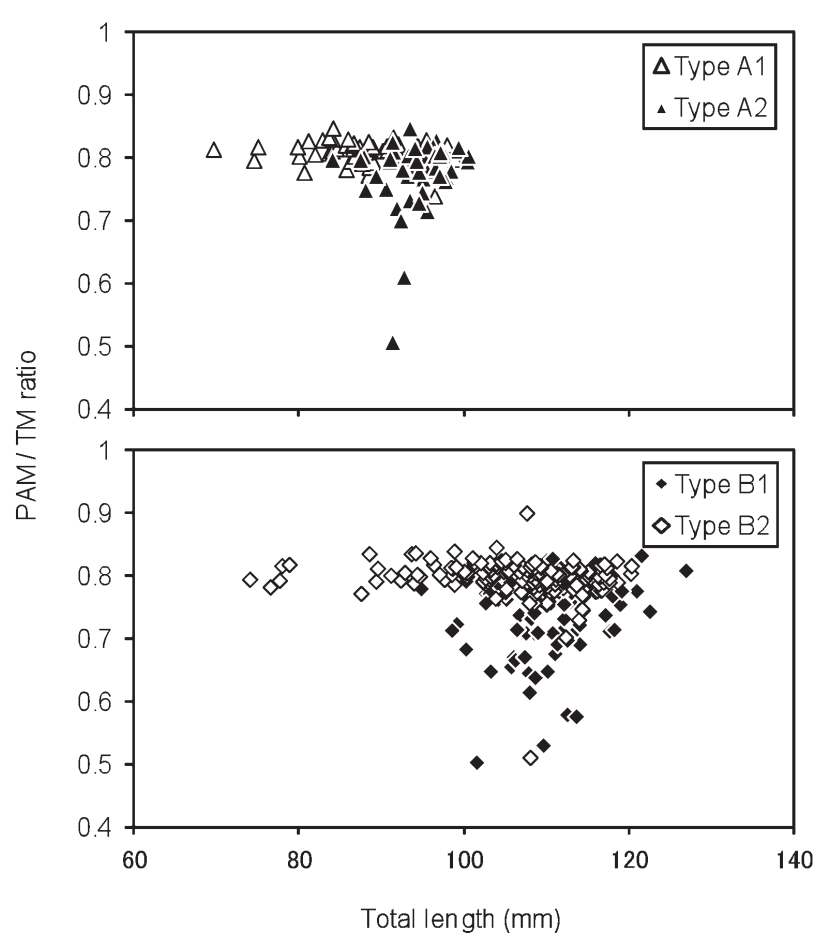

Fig. 3. Relationship between total length and pre-anal myomere (PAM) / total myomere (TM) ratio of each type of Gnathophis spp. leptocephali. and 0.082-0.127, respectively) (Table). Similarly, Types B1 (TM: 126-134, VBV last: 41-48, BH/TL ratio: 0.0930.137) and B2 (TM: 125-135, VBV last: 43-48, BH/TL ratio: 0.080-0.139) showed close morphological identities, there being no significant differences in TM ( $p>0.05$, t-test), VBV last ( $p>0.05$, t-test) and BH/TL ratio ( $p>0.05$, t-test) between Types $A 1$ and $A 2$, or Types B1 and B2.

Some morphometric or meristic characters showed significant difference among each groups or types. TL of Type A2 was significantly larger than that of Type A1 $(p<0.01$, t-test). TL of Type B1 was larger than that of Type B2 ( $<<0.01$, t-test). BH/TL ratio of Group B was significantly larger than that of Group A ( $p<0.01$, t-test) (Table). Relationship between TL and PAM/TM ratio showed significant difference among both Types A1 and $\mathrm{A} 2$ or B1 and B2 (Fig. 3, Table).

\section{Molecular genetic identification}

A total of 31 specimens, including adult $G$. heterognathos $(\mathrm{n}=6)$ and $G$. ginanago $(\mathrm{n}=5)$, and Type $\mathrm{A} 1$ $(n=5), A 2(n=4), B 1(n=5)$, and B2 $(n=6)$ leptocephali were subjected to DNA analysis, a total of 495 base pairs of the mitochondrial DNA 16S rRNA gene for each specimen being determined. Among the adult $G$. heterognathos and $G$. ginanago specimens, seven instances of interspecific variation were detected, at pair of 86,88 , a

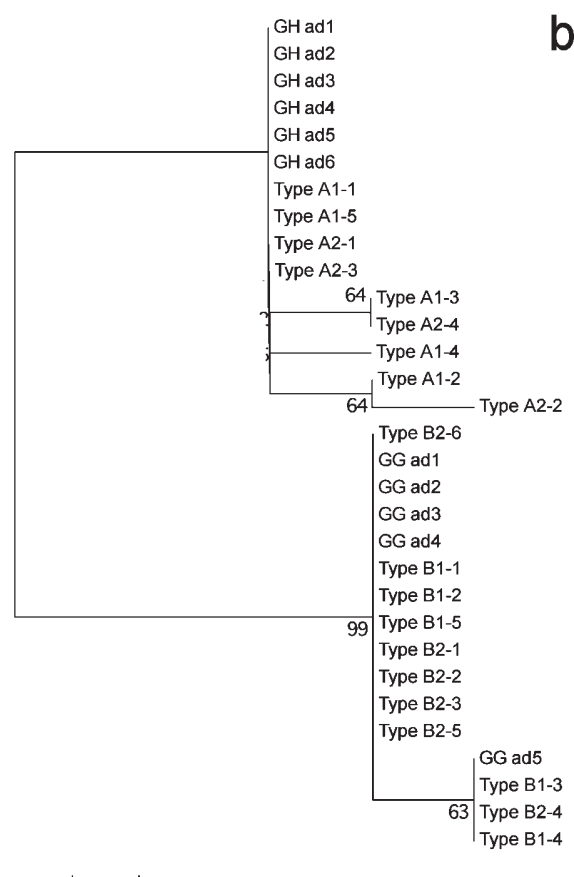

b

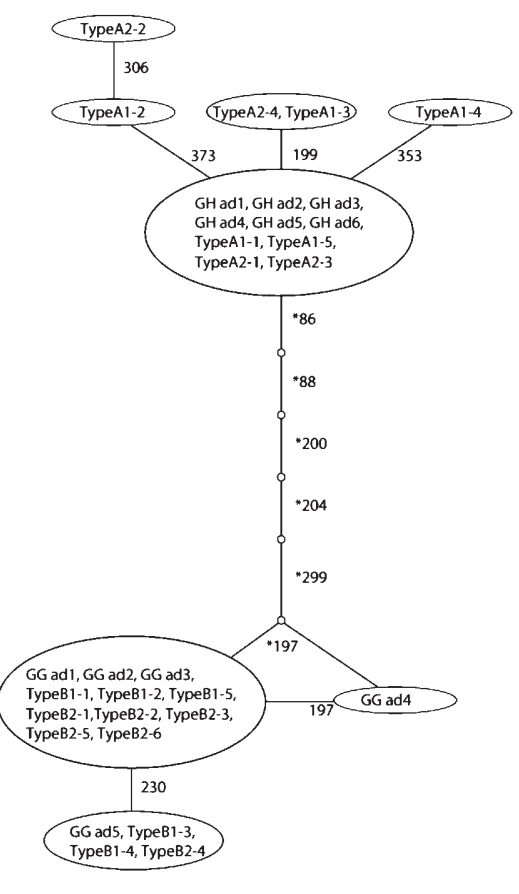

Fig. 4. a: Neighbor-Joining dendrogram for adults and leptocephali of Gnathophis spp. derived from mitochondrial DNA 16S rRNA gene sequences. b: Mitochondrial DNA 16S rRNA haplotype network estimated with 95\% statistical limits of parsimony using the algorithm in Templeton et al. (1992). Number of variable sites from the 5' end indicated. * shows number of nucleotide of interspecific variation. GH ad: adult of Gnathophis heterognathos, GG ad: adult of Gnathophis ginanago. 
197, 200, 204, 299, and 307. Single deletions (insertions) occurred between $G$. heterognathos and Group A (Types A1 and A2), and between G. ginanago and Group B (Types B1 and B2).

The neighbor-joining (NJ) dendrogram (Saitou and Nei, 1987) based on Kimura's two parameter model (Kimura, 1980), showed two clades with the 99\% bootstrap probabilities (Fig. 4a). Moreover, both clades were supported by the haplotype network according to the Statistical Parsimony method (Templeton et al., 1992) (Fig. 4b). Adult G. heterognathos, and Types A1 and A2 were included in one clade, while adult $G$. ginanago, and Types B1 and B2 were clustered in the other clade. The number of nucleotide replacement (sequence divergence) in the first clade was $0-3(0-0.61 \%)$, in the second clade, $0-1$ (0-0.20\%), and between each clade, 6-9 (1.21-1.81\%), which was higher than that of in each clade. Therefore, the Gnathophis spp. leptocephali could be reasonably identified as either $G$. heterognathos or G. ginanago.

\section{DISCUSSION}

Gnathophis leptocephali collected from the transition region were sorted into four types (Types A1, A2, B1, and B2) based on the currently accepted morphological analysis (Fig. 2, Table). Type A1 was characterized by 117-128 TM, 36-44 VBV last, and absent of posterior spinal cord melanophores. These characters matched those of $G$. heterognathos. Type A2 had almost the same range of TM (119-126) and VBV last (40-44) as A1, but posterior spinal cord melanophores were present. The characters of Type B1 (TM: 126-134, VBV last: 41-48, presence of posterior spinal cord melanophores) matched those of $G$. ginanago, and those of Type B2 having similar TM (125-135) and VBV last (43-48) values, but lacking posterior spinal cord melanophores.

Alignment analysis of the mitochondrial DNA $16 \mathrm{~S}$ rRNA gene of adult specimens indicated seven interspecific variations among $G$. heterognathos and $G$. ginanago. Intraspecific variations were not detected in adult of $G$. heterognathos, although one was apparent in $G$. ginanago. Clearly, adult of $G$. heterognathos and $G$. ginanago occupied different clades (Fig. 4). These results confirmed the validity of seven interspecific variations for discriminating between $G$. heterognathos and $G$. ginanago, the $16 \mathrm{~S}$ rRNA region therefore being useful for identifying the two species. Gnathophis leptocephali were also divided into two groups, Groups A (including Types A1 and A2) and B (including Types B1 and B2) (Fig. 4). These two groups have been characterized by the same interspecific variations seen in adult G. heterognathos and G. ginanago. As shown in Fig. 4, Types A1 and A2, and Types B1 and B2 were included in the same clades as adult of $G$. heterognathos and $G$. ginanago, respectively. These results are indicating that the two groups of leptocephali could be identified as $G$. heterognathos and $G$. ginanago, respectively.

Pigmentation characteristics of leptocephali, traces of which persist for a time in juveniles, can provide a valid basis for identifying some species (Smith, 1979), particularly so when myomere numbers overlap (Mochioka et al., 2014; Smith, 1989). However the present study raised questions regarding the validity of pigmentation for identification of leptocephali in this case. Furthermore, although a single row of lateral pigment has been recognized as a discriminating character of Conger myriaster leptocephali (Tabeta and Mochioka, 1988), resent studies have reported pattern variations in the midlateral pigmentations of $C$. myriaster (Kurogi, 2008). Ma et al. (2007) suggested that these varied pigmentation patterns of $C$. myriaster leptocephali were depend on their growth. Presence of posterior spinal cord melanophores was shown in specimens with larger TL or decreasing PAM/TM ratio in each species (Fig. 3). Specimens allocated to the two types in each species in the present study with significant difference in TL and PAM/TM ratio $(p<0.01$, t-test) (Table) suggested the morphological change with metamorphosis. Therefore pigment variations of these types of $G$. heterognathos and $G$. ginanago leptocephali were considered to depend on their growth and metamorphosis. As summarized in Table, 50 of 108 specimens of $G$. heterognathos leptocephali had inconsistent pigmentation patterns. Furthermore, 155 of 286 G. ginanago leptocephali also could not be identified by the described pigmentation pattern. These results indicate that "absence (presence) of posterior spinal cord melanophores (Tabeta and Mochioka, 1988)" should not be considered a diagnostic character of Gnathophis spp. leptochali.

The present study provides further evidence of the usefulness of DNA studies for clarification of larval species' identities, although the importance of morphological characters must also receive continuing emphasis.

\section{ACKNOWLEDGEMENTS}

We are grateful to K. Mori (Fisheries Agency), M. Takahashi (Seikai National Fisheries Research Institute, Fisheries Research Agency) and Y. Shiga (Kyushu University), who provided facilities for sample collecting and genetic analysis, and Captain T. Yoshino, and the officers and crews of the training vessel Hokuho Maru for their eager assistance. We also thank G. Hardy (Ngunguru, New Zealand) for critical comments on the manuscript. This work was partially funded by projects for research of marine fisheries stock assessment and evaluation for Japanese waters from the Fisheries Agency, Japan.

\section{REFERENCES}

Aoyama, J., S. Ishikawa, T. Otake, N. Mochioka, Y. Suzuki, S. Watanbe, A. Shinoda, J. Inoue, P. M. Lokman, T. Inagaki, M. Oya, H. Hasumoto, K. Kubokawa, T. W. Lee, H Fricke and K. Tsukamoto 2001 Molecular approach to species identification of eggs with respect to determination of the spawning site of the Japanese eel Anguilla japonica. Fish. Sci., 67: 761-763

Clement, A., D. Posada and K. A. Crandall 2000 TCS: a computer program to estimate gene genealogies. Mol. Ecol., 9: 16571660 
Efron, B. 1979 Bootstrap method: Another look at the jacknife. Ann. Stat., 7: 1-26

Greenwood, P. H., D. E. Rosen S. H. Weitzman G. S Myers 1966 Phyletic studies of teleostean fishes, with a provisional classification of living forms. Bull. Am. Mus. Nat. Hist., 131: 339-456

Hatooka, K. 2013 Congridae. In "Fishes of Japan with pictorial keys to the species, Third Edition" ed. by T. Nakabo, Tokai University Press, Kanagawa, pp. 227-234 (in Japanese)

Kimura, M. 1980 A simple method for estimating evolutionary rate of base substitutions through comparative studies of nucleotide sequences. J. Mol. Evol., 16: 111-120

Kimura, Y., M. J. Miller, G. Minagawa, S. Watanabe, A. Shinoda, J. Aoyama, T. Inagaki and K. Tsukamoto 2006 Evidence of a local spawning site of marine eels along northeastern Japan, based on the distribution of small leptocephali. Fish. Oceanogr., 15: 183-190

Kumar, S., K. Tamura and M. Nei 2004 MEGA3: integrated software for molecular evolutionary genetics analysis and sequence alignment. Briefings in Bioinformatics., 5: 150-163

Kurogi, H. 2008 Study on the inshore migration mechanism of Conger myriaster leptocephali. Bull. Fish. Res. Agen., 24: $105-152$

Lee, T. W. and J. S. Byun 1996 Daily growth increments and lunar pattern in otolith of the eel, Anguilla japonica, in the freshwater. Bull. Korean Fish. Soc., 22: 36-40

Ma, T., M. J. Miller, A. Shinoda, G. Minagawa, J. Aoyama and K. Tsukamoto 2005 Age and growth of Saurenchelys (Nettastomatidae) and Dysomma (Synaphobranchidae) leptocephali in the East China Sea. J. Fish. Biol., 67: 1619-1630

Ma, T., M. J. Miller, J. Aoyama and K. Tsukamoto 2007 Genetic identification of Conger myriaster leptocephali in East China Sea. Fish. Sci., 73: 989-994

Miller, M. J., T. Otake, G. Minagawa, T. Inagaki and K. Tsukamoto 2002 Distribution of leptocephali in the Kuroshio Current region and the East China Sea. Mar. Ecol. Prog. Ser., 235: 279-288

Miya, M. and M. Hirosawa 1994 Anguilliform leptocephali from a fixed station in Sagami Bay, Central Japan. Japan J. Ichthyol., 41: 68-72 Mochioka, N., S. Shiozawa, M. Nagasaka and T. Kubota 2001 Elopiform, Albuliform and Anguilliform leptocephalus larvae in Suruga Bay, central Japan. J. School Marine Sci. Tech. Tokai Univ., 52: 43-55 (in Japanese)

Mochioka N, O. Tabeta, A. Tawa and M. Takahashi 2014 Anguilliformes. In "An atlas of early stage fishes in Japan Second Edition (in Japanese)", ed. by M. Okiyama, Tokai University press, Tokyo, pp. 13-89 (in Japanese)

Nelson, J. S. 2006 Fishes of the world, 4th edition. John Wiley \& Sons, New York, pp. 108-125

Saitou, N. and M. Nei 1987 The Neighbor-joining method: a new method for reconstructing phylogenetic trees. Mol. Biol. Evol.,
4: $406-425$

Smith, D. G. 1979 Guide to the leptocephali (Elopiformes, Anguilliformes and Notacanthiformes). NOAA. Tech. Rep. NMFS Circ., 424: 1-39

Smith, D. G. 1989 Introduction to leptocephali. In "Fishes of the western North Atlantic" Part 9 ed. by E. B. Bölke, New Heaven, Connecticut, pp. 657-668

Tabeta O, Mochioka N 1988 Leptocephali. In: Okiyama M (ed.) An atlas of the early stage fishes in Japan (in Japanese). Tokai University press, Tokyo, pp. 15-64 (in Japanese)

Takahashi, M., N. Mochioka, S. Shinagawa, A. Yatsu and A. Nakazono 2008 Distribution patterns of leptocephali in the KuroshioOyashio transitional region of the western North Pacific. Fish. Oceanogr., 17: 165-177

Tanaka, K, O. Tabata, N. Mochioka, J. Yamada and S. Kakuda 1987 Otolith microstructure and ecology of the conger eel (Conger myriaster) larvae in the Seto Inland Sea. Suisan Kaiyo Kenkyu., 53: 543-549

Tawa, A. and N. Mochioka 2009 Identification of aquarium-raised muraenid leptocephali, Gymnothorax minor. Ichthyol. Res. 56: $340-345$

Tawa, A., M. Kobayakawa, T. Yoshimura and N. Mochioka 2012 Identification of leptocephalus larvae of the tiger moray Scuticaria tigrina (Anguilliformes; Muraenidae) based on morphometric and genetic evidence. Ichthyol. Res., 59: 378383

Templeton, A. R., K. A. Crandall and C. F. Sing 1992 A cladistic analysis of phenotypic associations with haplotypes inferred from restriction endonuclease mapping and DNA sequence data. III. Cladogram estimation. Genetics, 132: 619-633

Thompson, J. D., T. J. Gibson, F. Plewniak, F. Jeanmougin and D. G. Higgins 1997 The ClustalX windows interface: flexible strategies for multiple sequence alignment aided by quality analysis tools. Nucleic Acids Res., 24: 4876-4882

Uematsu, K., T. Otake, H. Kurokura, K. Tsukamoto, M. Oya and A. Go 1990 Anguilliformes Leptocephali from the Tosa Bay and the waters off Shikoku Island. J. Fac. Appl. Biol. Sci., Hiroshima Univ., 29: 11-18

Uematsu, K., T. Otake, Y. Tsukamoto, Y. Sakakura, H. Kurokura, H Hasumoto and K. Tsukamoto 1992 Distribution of leptocephali and other fish larvae around the Tanegashima Island, with special reference to the coastal migration of Anguilla japonica. J. Fac. Appl. Biol. Sci., Hiroshima Univ., 31 161-172

Watanabe, S., Y. Minegishi, T. Yoshinaga, J. Aoyama and K. Tukamoto 2004 A quick method for species identification of Japanese eel (Anguilla japonica) using Real-Time PCR: an onboard application for use during sampling surveys. Mar. Biotechnol., 6: 66-574 